\title{
The geological and hydrogeological characteristics of Tamelast landfill site in Agadir, Morocco
}

\author{
Saadia Asouam ${ }^{1,}$, Farid Faik ${ }^{1}$, Zine El Abidine El Morjani ${ }^{2}$, and Mohamed Abioui ${ }^{1}$ \\ ${ }^{1}$ Department of Earth Sciences, Faculty of Sciences, Ibn Zohr University, Agadir, Morocco \\ ${ }^{2}$ Polydisciplinary Faculty of Taroudant, Ibn Zohr University, Taroudant, Morocco
}

\begin{abstract}
The Grand Agadir is confronting with huge production of solid waste. Due to the fact of changes in habits of consumption, the increase of production, and demographic evolution. This production is buried in the controlled discharge of Tamelast. This landfill faces many environmental issues. Our work aims to evaluate the environmental characteristics based on the geological and hydrogeological properties of the site of the Tamelast landfill in Grand Agadir (Morocco). To evaluate the geological and hydrogeological characteristics of the Tamelast landfill, we have generated geological, hydrogeological maps, stratigraphic vertical sections, and cross-sections of the landfill area that have been prepared for further assessment of environmental geological factors. Besides, we also focused on other measures of permeability, and field data we could define the probability and importance of contamination by leachate. The Tamelast landfill is installed on the marl-limestone and carbonate ranges of the Campanian and Maastrichtian. Geologically, the site consists essentially of carbonate deposits, limestones, and Cretaceous marls. These geological outcrops that can play the role of a potential aquifer are the fractured Campanian marl-limestone formations. These soils have a permeability of $5.10-4$ to $10-3 \mathrm{~m} / \mathrm{s}$ and transmissivity of $10-2$ to $5.10-2 \mathrm{~m} 2 / \mathrm{s}$.
\end{abstract}

\section{Introduction}

Globally, waste management problems have become a major menace to the natural environment in developing countries (e.g., Morocco) and efficient solutions are urgently needed [1]. Firstly, the most used methods for the elimination of solid waste are composting, incineration, and controlled landfills. Landfills are most often used for the final elimination of municipal solid waste. But an inevitable consequence of this practice is the generation of leachate [1]. Thirdly, Municipal waste disposal has posed a serious environmental threat to human existence in the urban centers of the world's developing countries [2]. Lastly, the decision-makers try to eliminate solid waste in landfills without causing any impacts on the environment, human health, and amenity. The selection of a controlled landfill for the storage of municipal waste requires very careful environmental, geological, and hydrogeological studies [3]. Therefore, selecting a suitable site for municipal waste disposal is considered the most important step in the development and management of solid waste. In the selection of sites, geological nature and hydrology play a very primordial role [3]. These criteria mainly control the suitability of waste disposal sites and the importance of bedrock geology and drift for groundwater protection is the decision-makers emphasized.

Since 2010, the landfill has been operating as part of the delegated management adopted by the Agadir Municipality after the rehabilitation and closure of the uncontrolled landfill with a surface area of 41 ha. The landfill of Tamelast is characterized by the installation of two storage lockers on a surface area of 12 ha and six leachate storage basins; to avoid the problem of leachate infiltration, the managers have installed an active membrane system: bentonites, geomembranes, and geotextiles (Fig. 1) [4].

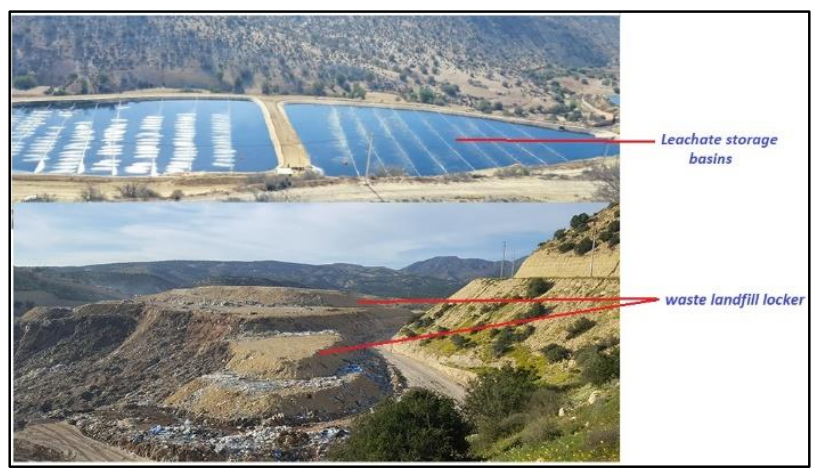

Fig.1. Panoramic view of Landfill of Tamelast (Source: Field survey, 2017).

\section{Materials, methods and data collection}

To evaluate the geological and hydrogeological characteristics of the Tamelast landfill, we have used many data: geological, hydrogeological maps, and measurement of permeability and porosity. Investigation

\footnotetext{
*Corresponding author: saadia.asouam@gmail.com
} 
of outcrops, as well as boreholes in the Tamelast landfill, provides an excellent opportunity for carrying out a complete study of this landfill. Therefore, GIS and spatial databases were created.

\section{Geographical setting of the Tamelast landfill}

The Tamelast landfill is located east of the city of Agadir, on the southwestern slope of the High Atlas Mountains. It is located on the first hills between the plain of Mesguina and the reliefs of the Atlas Mountains. It is limited geographically by the valleys of the river of Tamelast in the NW and Smoumène River in the SE (Fig. 2). It is accessible by the asphalt road leading to the new stadium of Agadir Adrar and the village of Tamelast; the geographical coordinates are N 30²6'29", W 9०30'40".

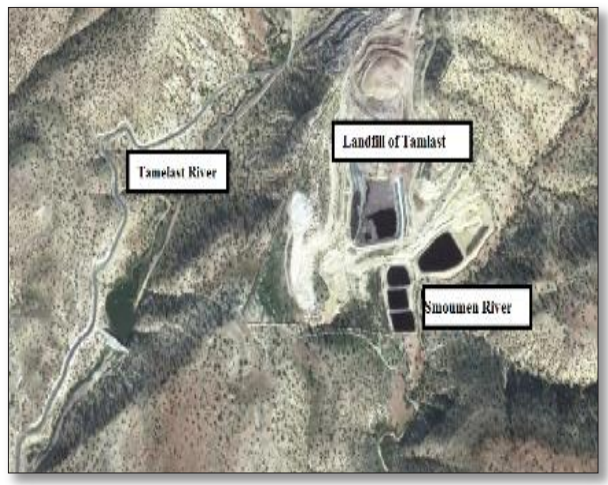

Fig. 2. Location of the Tamelast landfill (Google Earth, 2020).

\section{Geological context of the Tamelast landfill}

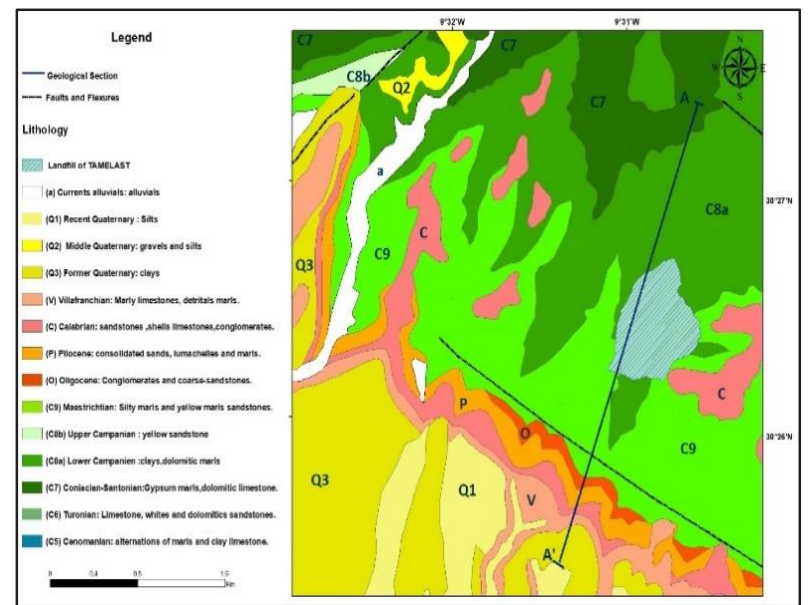

Fig. 3. Simplified geological map of the Tamelast site (Extract from the geological map of Agadir at 1/50000 [5]).

The Tamelast site is geologically located on the Upper Cretaceous carbonate formations, which are covered by silt and carbonate deposits of the middle and recent Quaternary deposits of the Mesguina plain (Fig. 3). According to the geological map of Agadir au 1/50 000 [5] and field data, the Tamelast technical landfill is installed on the marl-limestone and carbonate ranges of the Campanian-Maastrichtian ages (Fig. 3).

\section{Stratigraphy of Tamelast landfill}

According to the geological map and field surveys, the Tamelast landfill consists mostly of Upper Cretaceous deposits (Figs. 4, 5, and 6).

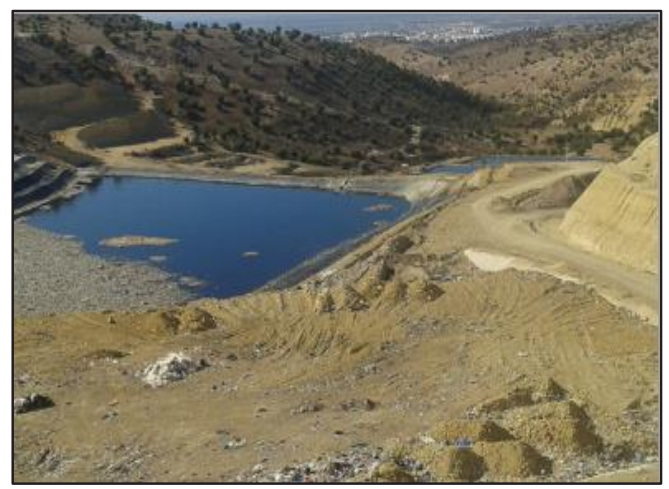

Fig.4. Tamelast discharge on the Campanian carbonates series (Source: Field survey 2017).

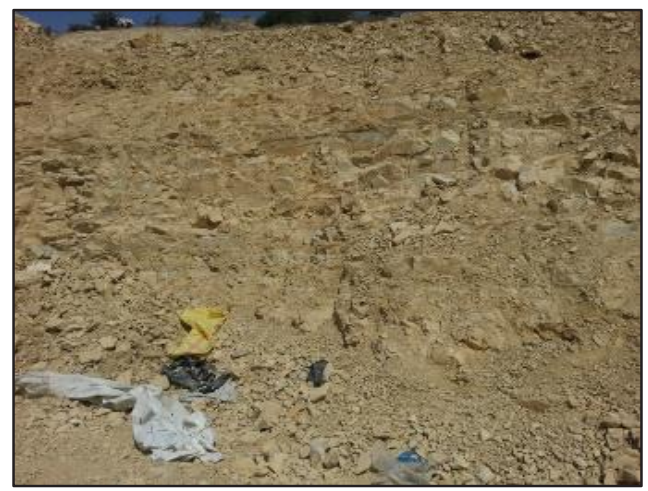

Fig.5. The Campanian yellow limestone and whitish marl beds (Source: Field survey, 2017).

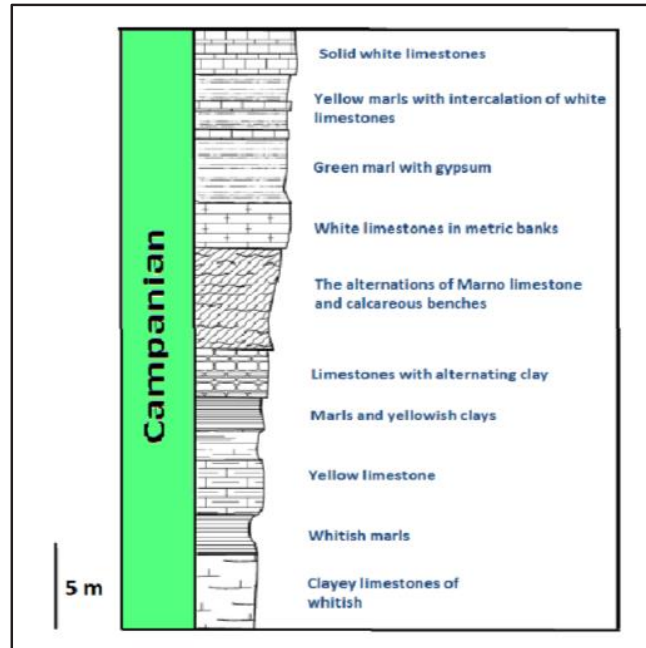

Fig.6. A detailed description of the Campanian stratigraphic series of the Tamelast region watershed (redraw from [5]).

Sedimentological observations were made along the Tamelast landfill except in the inaccessible south-east area. From the stratigraphical point of view, the series 
begins with very fine micritic whitish clayey limestones in decimetric banks (Fig.7), surmounted by whitish marls made up of very fine clayey particles. At $5 \mathrm{~m}$ from the base, there is a sharp transition to yellow limestones in benches of 10 to $20 \mathrm{~cm}$, rich in shells and alternating with fine marly levels. Additionally, the series continues with $10 \mathrm{~m}$ thick of yellowish marls and clays, then alternating banks of fine limestone and marly clays. Thin, above the deposits, become more sandstone and sandstone limestone levels with a reddish color showing an influence of alteration by iron oxides (Fig.7). Westward, the thickness becomes finer again by an alternation of marls and fine limestone beds (Fig.8). The uppermost $10 \mathrm{~m}$ of the section consists of intervals that are gypsum-rich yellow marly deposits and massive white limestones in metric beds with shell-rich levels (Fig.9).

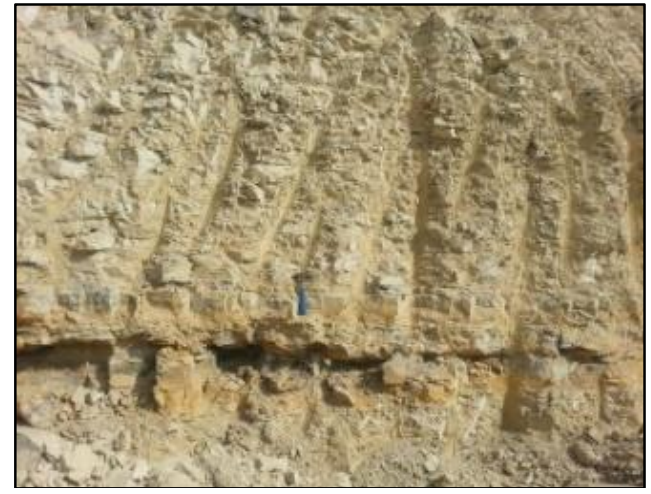

Fig.7. Whitish limestone with reddish levels due to alteration by iron oxides (Source: Field survey, 2017). Hammer for scale.

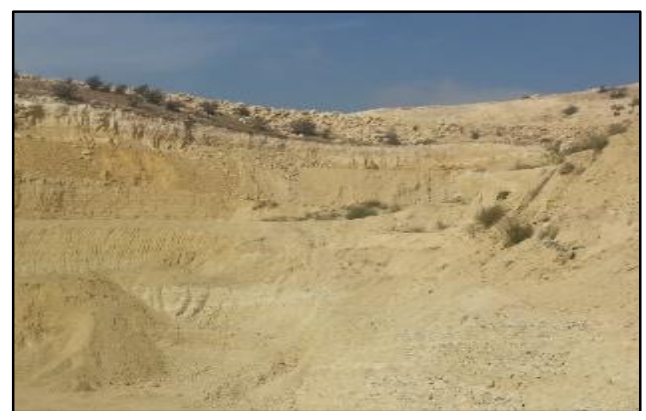

Fig.8. Alternation of the yellow limestone and marl levels (Source: Field survey, 2017).

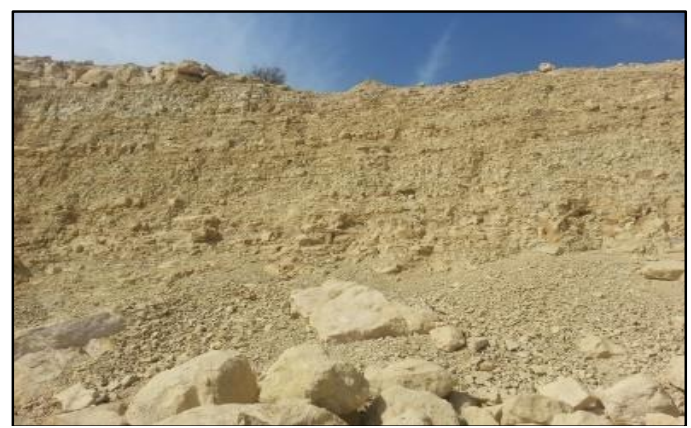

Fig.9. Campanian series with alternating limestones, marls, and massive limestone banks at the top (Source: Field survey, 2017). Strata thickness is not at scale.

The description of the stratigraphic series shows an abundance of clay and marl levels alternating with limestone banks. The presence of clay and marl layers plays an important role in the permeability to leachates, as clays are known to have a low permeability to fluids.

\section{Structural frameworks}

From the structural study, the Tamelast site is located south of the South Atlas Fault (SAF: the main structural framework in this region), thus outside the deformed Atlasic domain. Folds and faults are widely developed in different directions (Figs. 10, 11, and 12).

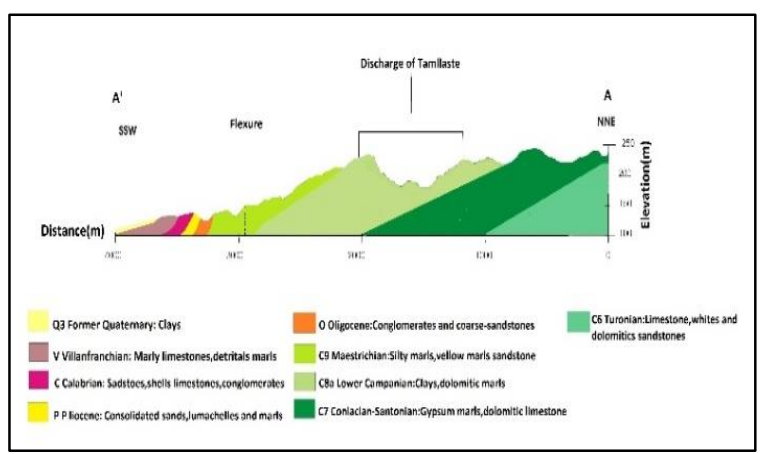

Fig.10. Geological section through the Tamelast site (AA' section on the map) (redraw from [5]).

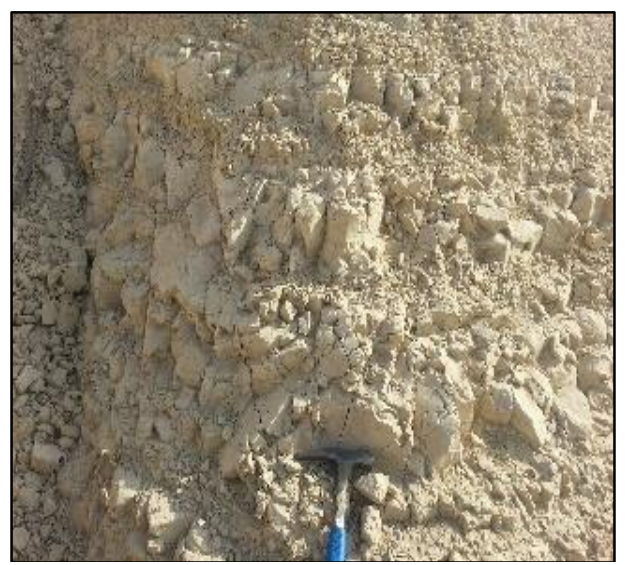

Fig. 11. Limestone layers dipping slightly to the South and highly fractured (Source: Field survey, 2017). Hammer for scale.

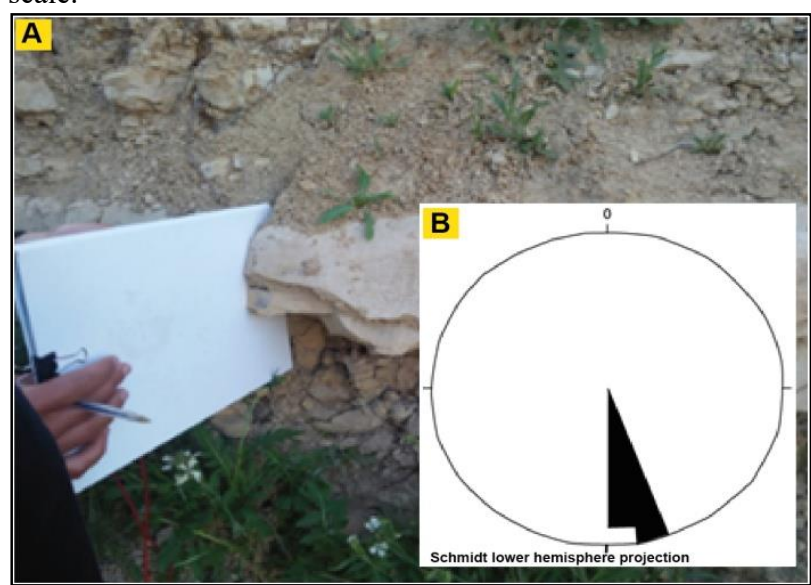

Fig.12. A Measurement of strike and dip of joints (Source: Field survey, 2017). B Rosace stereonet Stereographic plot (Schmidt lower hemisphere projection) of the structural elements in the Tamelast limestone beds. 


\section{Natural hazards}

In February 2017, the Tamelast landfill site experienced a slide of a household waste landfill locker to a leachate collection basin (Fig. 14), this slide was induced by an earthquake that hit the south of Agadir causing a large quantity of leachate to flow out, causing damage to the geomembranes and inducing a risk of leachate infiltration into surface water and in the groundwater.

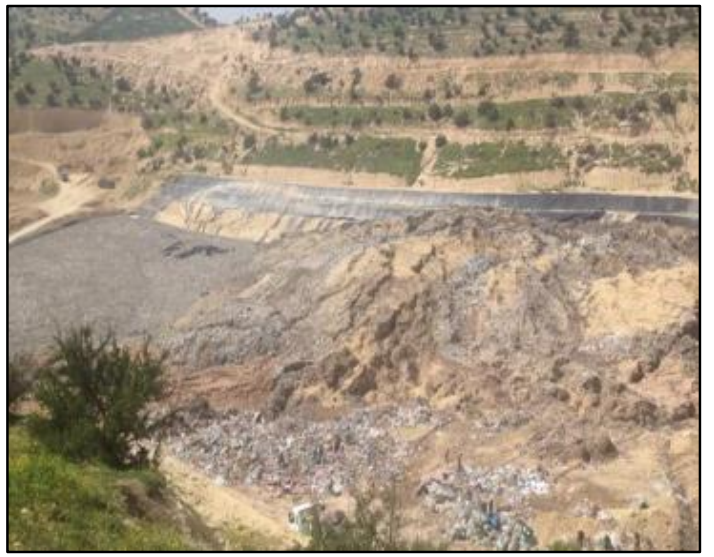

Fig.13. Slide of a damaged household waste landfill locker (Source: Field survey, 2017).

The study area is located in an area that is highly vulnerable to groundwater pollution. Also, the Tamelast site is influenced by the impacts of geohazards, landslides, and earthquakes that have been registered.

Local environmental features such as faults, landslides, and earthquakes (Fig.13) show that the landfill area is under imminent threat from natural hazards. In this context, the waste disposal area is sensitive to natural and environmental disturbances.

\section{Hydrographic networks}

The study site is located in the downstream part between the confluence of the Taquenza and Lahouar River. It is part of the sub-watershed drained by the Smoumène river tributary, the left bank of Tamelast River (Figs. 14 and 15).

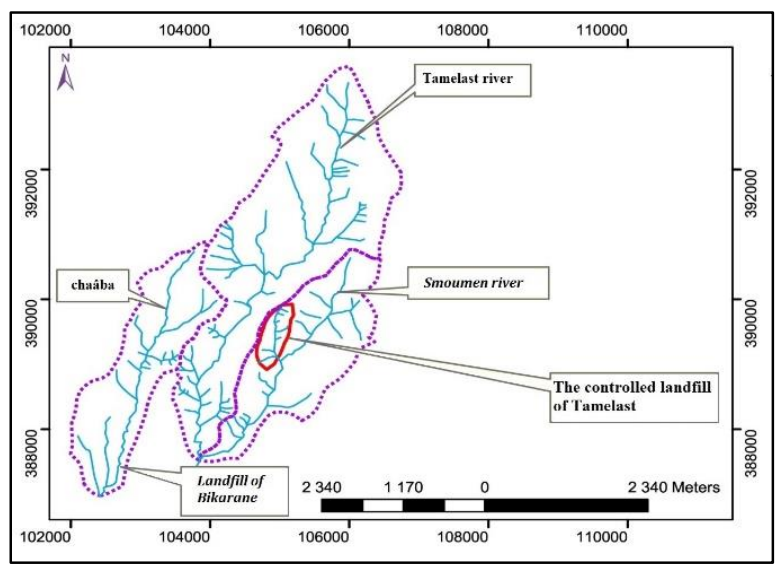

Fig.14. Local hydrographic network.
The Tamelast landfill is drained by the river of Tamelast and its tributary river of Smoumène. The network consisting of these two rivers drains (from the point of confluence) a watershed with a surface area of $11 \mathrm{~km}^{2}$. This basin is subdivided into two sub-basins (Fig. 15): Smoumène sub-basin and Tamelast sub-basin.

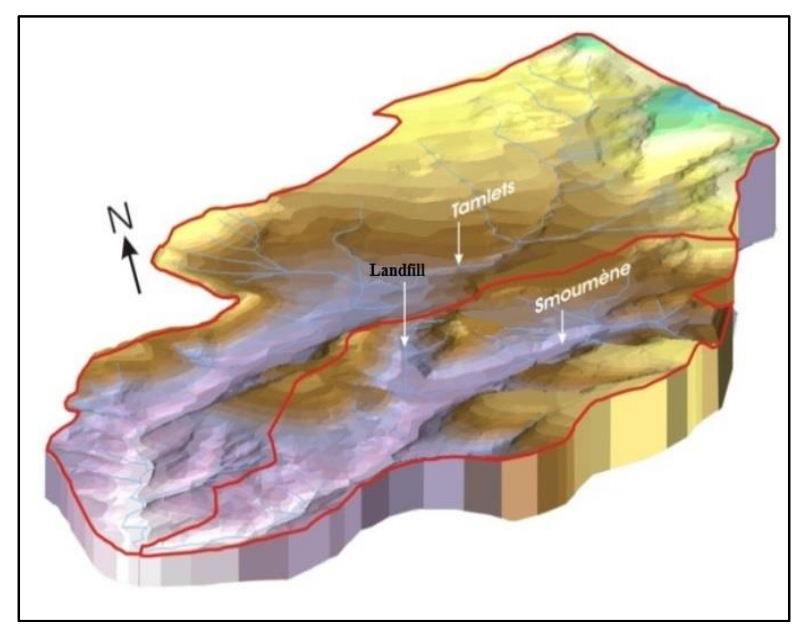

Fig.15. 3D view of the two sub-basins of Tamelast and Smoumène rivers.

The hypsometric curves established for the two subbasins of Tamelast and Smoumène characterize young basins where the area is small compared to the initial altitude change, which is characteristic of steep slopes (Fig. 16).

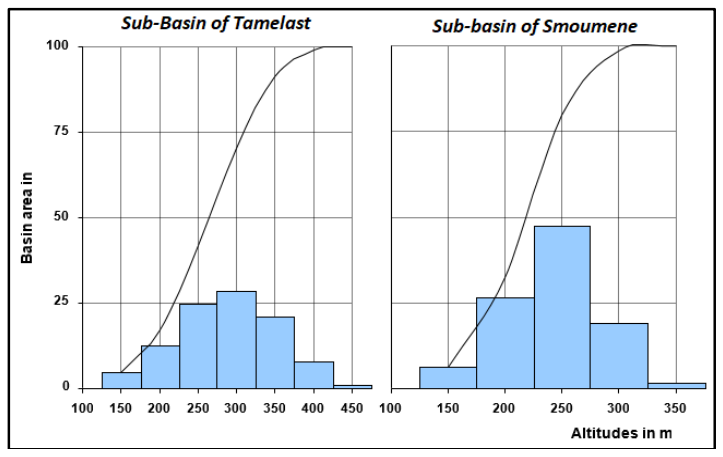

Fig.16. Hypsometric curves and histograms of the altimetry frequency of the sub-basins of Tamelast and Smoumène (Source: Souss-Massa Hydraulic Basin Agency).

The longitudinal profiles of the two main rivers show that the Tamelast River begins its course with a strong slope of $9 \%$ which gradually decreases to reach $2.6 \%$ at the confluence point over a length of $7.2 \mathrm{~km}$. At the level of the Smoumène sub-basin, the $4.2 \mathrm{~km}$-long river has a slope that decreases irregularly over six stages, from $6 \%$ to $1.9 \%$ at the confluence point (Fig. 17). The average slopes of the two rivers, calculated according to the weighting method are of the order of $4.5 \%$ for Tamelast and $4.7 \%$ for Smoumène. The calculation of the drainage density at the level of the two sub-basins of Tamelast and Smoumène gives respective coefficients of 2.99 and 3.07. These very low coefficients characterize areas with rudimentary and centralized flow and/or highly permeable bedrock. 


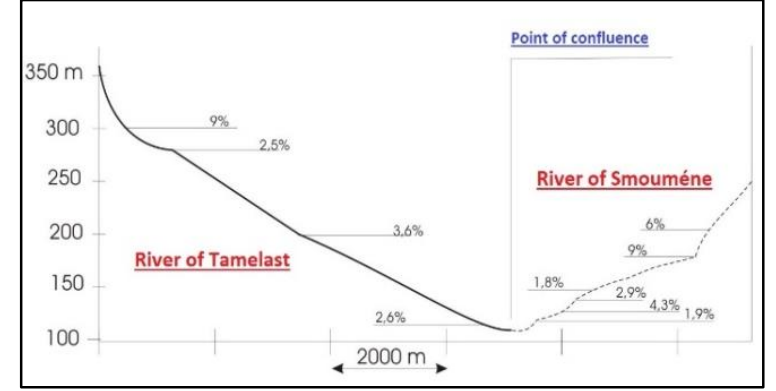

Fig.17. Bed profiles of Tamelast River and its tributary Smoumène River.

\subsection{Local hydrogeology}

According to some unpublished Environmental Impact Assessment (EIA) studies already carried out in the Tamelast Landfill, the geological outcrops that can act as potential aquifers are the Campanian fractured marlcalcareous formations and the Quaternary. These lands have a permeability of $5.10^{-4}$ to $10^{-3} \mathrm{~m} / \mathrm{s}$ and transmissivity of $10^{-2}$ to $5.10^{-2} \mathrm{~m}^{2} / \mathrm{s}$.

Based on data from fifty wells and boreholes located in the Agadir region were collected, analyzed, and inventoried by the Souss-Massa Hydraulic Basin Agency (ABHSM) (Fig. 18). Noted that the wells are located near the old Bikarane landfill and the Tamelast landfill. The wells P45 to P48 located near the Tamelast landfill, capture the water in limestone and marl-limestone (Campanian), and are used for rural drinking water supply. The other water points capture the quaternary levels and are used for industrial purposes and drinking water supply (ONEEP).

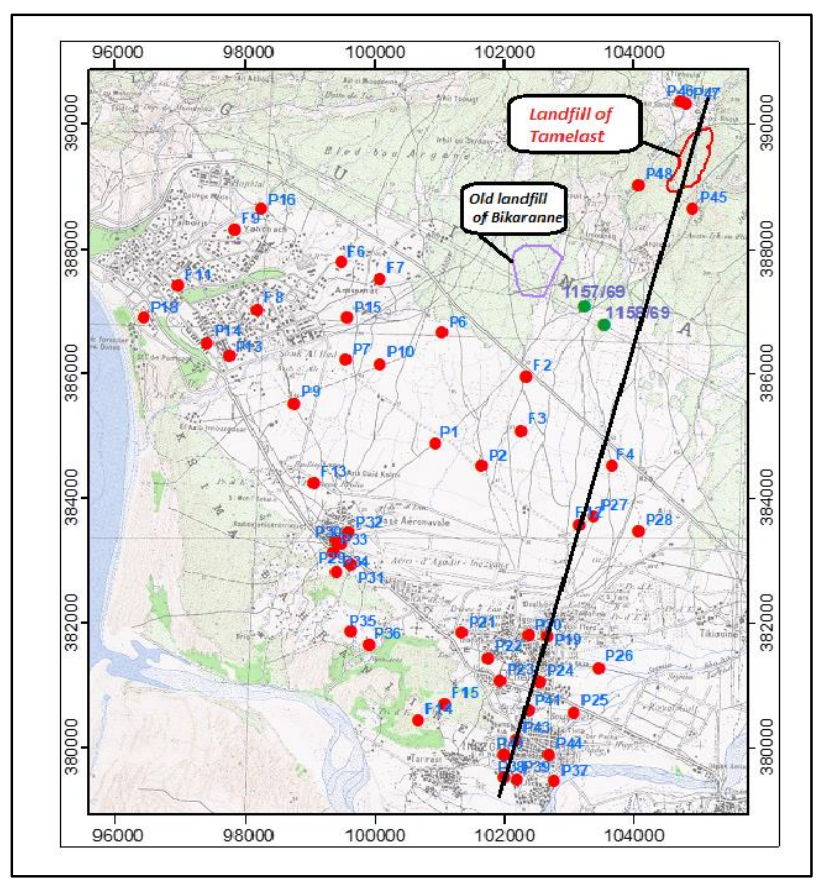

Fig.18. The situation of wells and boreholes on the topographic map (Source: Souss-Massa Hydraulic Basin Agency).
The data concerning the piezometric level of inventoried wells and boreholes are not contemporary and have not been used for this purpose for the establishment of a piezometric map. These piezometric levels, comparable to those used for the establishment of the piezometric map of the free water tables of Souss and Chtouka, make it possible to connect these inventoried wells to the water table of Souss except for the wells located near the landfill of Tamelast (Fig. 18).

A NE-SW piezometric section passing through the Tamelast landfill was carried out with 10 wells and boreholes. It highlights the existence of a hydraulic discontinuity between the wells P47 and F4 (Fig. 19). This discontinuity coincides with the NW-SE great NWSE flexion mentioned in the section on the geological setting and bringing into contact the limestone and marllimestone of the Campanian with the Quaternary.

An inversion of the hydraulic gradient is shown in this section at the level of borehole F4. This inversion can be explained by overexploitation of the water table at the level of borehole F4 or simply by the noncontemporaneity of the piezometric measurements.

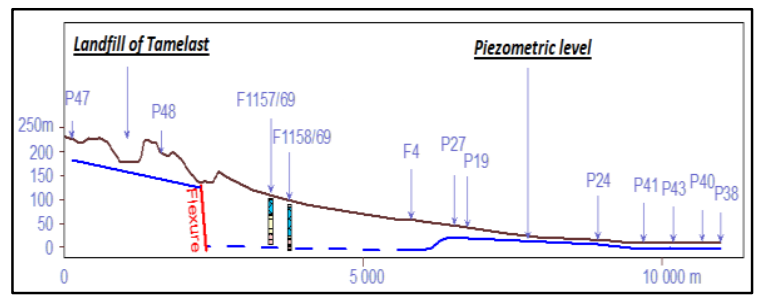

Fig.19. Piezometric section through the Tamelast landfill (Source: Souss-Massa Hydraulic Basin Agency).

Between wells P48 and F4, two holes (1157/69 and $1158 / 69)$ of depth $100 \mathrm{~m}$ were projected on the piezometric section. Drill 1158/69 showed a very low flow of water at a depth of $94.5 \mathrm{~m}$ at $0.5 \mathrm{~m} / \mathrm{NGM}$ while $1157 / 69$ was dry. The correlation between these two drillings revealed two different levels of global lithologies (Fig. 20). After the digging of 3 to $4 \mathrm{~m}$, a level of limestones with marly intercalations rests on brown and yellow clays.

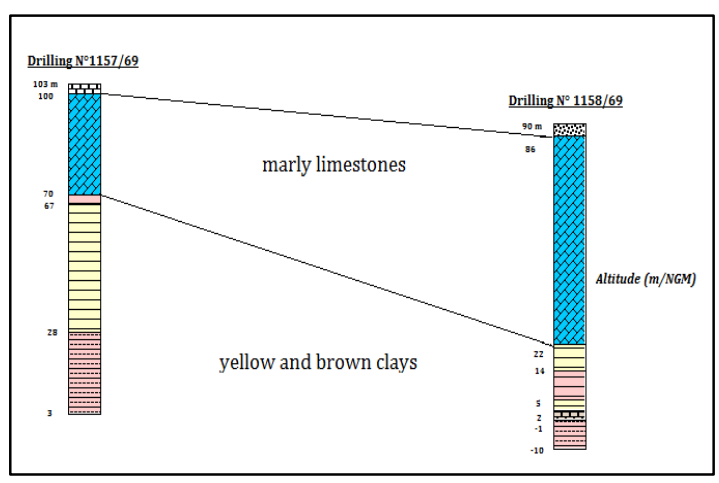

Fig. 20. Corrected bore logs $1157 / 69$ and $1158 / 69$ (Source: Souss-Massa Hydraulic Basin Agency). 
As a result, the Tamelast technical landfill site is located in an area with a very limited water table in the limestone and marl-limestone of the Campanian. This table cloth can be captured less than $20 \mathrm{~m}$ below the landfill of Tamelast.

\subsection{Permeability}

The generalized aquifer presents a lateral variation of facies that affects the distribution of permeabilities [6]. The map (Fig. 21) shows variable permeabilities ranging from $10^{-5} \mathrm{~m} / \mathrm{s}$ to $2.10^{-2} \mathrm{~m} / \mathrm{s}$. Transmissivity is also characterized by a very wide spatial distribution $\left(10^{-4}\right.$ $\mathrm{m}^{2} / \mathrm{s}$ to $10^{-1} \mathrm{~m}^{2} / \mathrm{s}$ ). This variation is explained by the structure of the aquifer, the topography of the aquifer, and the heterogeneity of the materials constituting this aquifer.

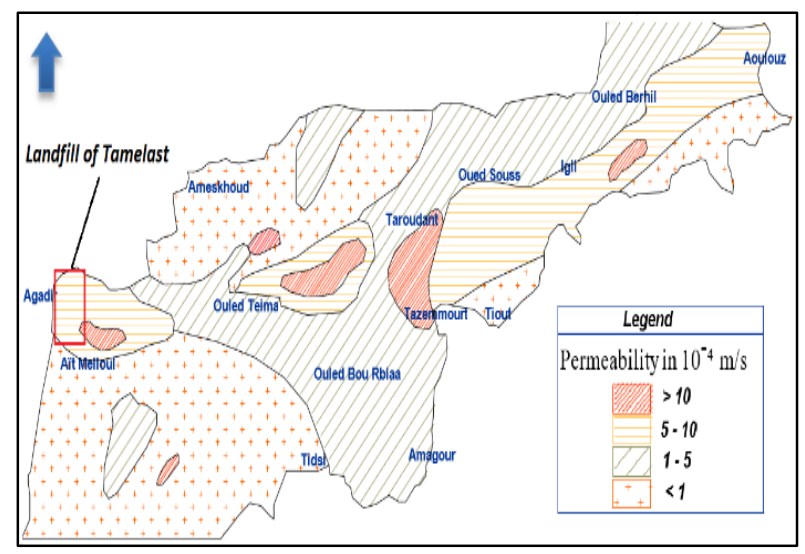

Fig.21. Map of permeability of soil in the plain of Souss (Source: Souss-Massa Hydraulic Basin Agency).

The study site is located in the permeability zone from $5.10^{-4}$ to $10^{-3} \mathrm{~m} / \mathrm{s}$ (Fig. 21). These values correspond to gravelly alluvial soils with little clay (Quaternary) and the highly fractured marl-limestone outcrops (Campanian).

\subsection{Transmissivity}

According to an unpublished report (Souss-Massa Hydraulic Basin Agency), the analysis of the transmissivity map suggested that the landfill site is located in the transmissivity zone from $10^{-2}$ to $5.10^{-2}$ $\mathrm{m}^{2} / \mathrm{s}$.

In general, many rocks are impermeable; it is enough for this to be made up of fine grains with extremely small joints between the grains so that water does not circulate: As a result, their porosity is very low [6].

The problem is that these rocks can become permeable when fractured; this is called fracture permeability. In this case, they can allow the circulation of water, this is what characterizes the permeability and therefore contain aquifers [6].

\subsection{Permeability of carbonate rocks of Tamelast}

Normally, limestones and marls are impermeable, but in the case of the Campanian carbonate series of Tamelast landfill, but the presence of fractures can make them permeable, and caused the infiltration of the leachate. For this reason, the company managing this landfill site uses geomembranes in all leachate treatment basins to prevent infiltration and avoid contamination (Fig. 22).

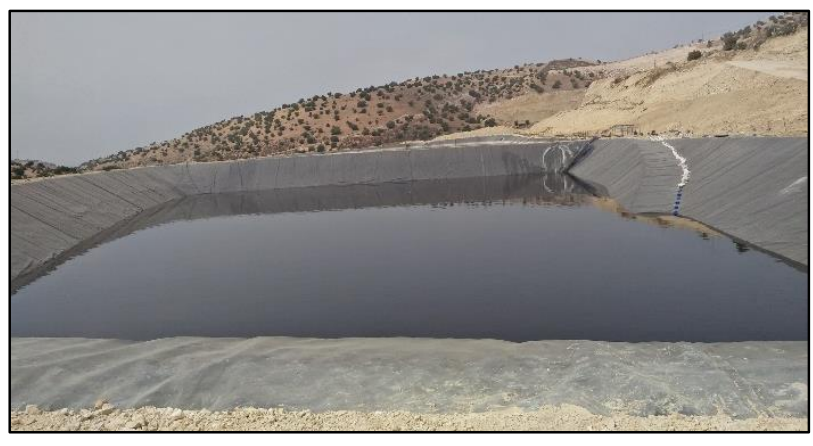

Fig.22. Geomembrane of the leachate storage basin at the Tamelast landfill site.

\section{Conclusions and future suggestions}

Environmental geology provides methods to study the information required for the installation of a controlled landfill. However, environmental hazards such as runoff, river flooding, landslides, and earthquakes generally affect landfills. They are affected by changing environmental conditions. Further, the environmental geology of landfill areas must be examined in detail. The databases indicate that the geological nature and the position of the landfill play the most determining role in minimizing the pollution's impacts. Therefore, these results involved in this study will guide to select another suitable site to solve the environmental issues caused by Tamelast discharge with the application of the multi-criteria analysis. This short paper provides a basis for the scientific utilization and choice of a landfill site in the future, groundwater resources, and sustainable development of the ecological environment.

Municipal solid waste is emerging as a big environmental issue in Agadir City and is nowadays a subject of great importance and complexity. Thus, creating value for waste management is always associated with uncertainty and risk. This study is limited and the future development of this work will focus on practical tests. On the other hand, the work would be also extended to develop an artificial intelligence proposal and the development of new treatment technologies and the implementation of economic instruments for an intelligent and autonomous demand-response waste management system, based on a fully interactive infrastructure that meets specific requirements, the main purpose of which, by the cooperation between the Municipality of Agadir and the university, is to help the related decision-makers can use the results prepared within the scope of the study in accordance with the national/international literature, national/international standards and scientific facts, and 
adapt them to their own works. For future research, other types of contracts between the Tamelast Landfill Site and the ecological and environmental concerns (such as chemistry, artificial intelligence, geology, hydrology, and environmental impact assessment, evaluation of GISbased multi-criteria decision-making methods for sanitary landfill site selection when the Tamelast Landfill full) are worth studying.

Acknowledgments. The authors address their warmest thanks to the Wilaya de Souss-Massa, Municipality of Agadir, Observatoire Régional de l'Environnement et de Développement Durable du Souss Massa, and Souss-Massa Hydraulic Basin Agency (ABHSM) for providing the data used in this study. Finally, we thank two anonymous reviewers for their insightful comments that improved the flow and direction of the manuscript.

\section{References}

1. R. Arjwech, K. Somchat, P. Pondthai, M. Everett, M. Schulmeister, S. Saengchomphu, Assessment of Geological, Hydrogeological and Geotechnical Characteristics of a Proposed Waste Disposal Site: A Case Study in Khon Kaen, Thailand, Geosciences, 10(3), 109 (2020).

2. İ.H. Yılmaz, A. Abdulvahitoğlu, Evaluation of municipal solid waste options in Turkey: Scenarios for energy recovery, carbon mitigation and consequent financial strategies, Resour. Conserv. Recy., 147, 95-110 (2019).

3. M. Kamil, K. M. Ramadan, O. I. Awad, T.K. Ibrahim, A. Inayat, X. Ma, Environmental impacts of biodiesel production from waste spent coffee grounds and its implementation in a compression ignition engine. Sci. Total Environ., 675, 13-30 (2019).

4. S. Asouam, F. Faik, Z. E. A. El Morjani, Geological study for choosing the right site for disposal of solid Waste (Grand Agadir, Morocco), in Proceedings of the la deuxième édition des Journées Géologiques du Maroc, Ministère de l'Energie, des Mines et du Développement Durable, 8-9 May 2018, Rabat, Morocco (2018).

5. R. Ambroggi, Etude géologique du versant méridional du Haut Atlas occidental et de la plaine du Souss, Notes \& Mém. Serv. Géol. Maroc, 157, 322 p (1963).

6. AFNOR, Guide de bonnes pratiques pour les reconnaissances géologiques, hydrogéologiques et géotechniques de sites d'installations de stockage de déchets, AFNOR BP X 30-438, 46 p (2009). 